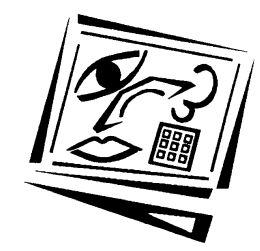

\title{
Digital mismatch: Expectations and realities of digital competency amongst pre-service education students
}

\author{
Jennifer Duncan-Howell \\ Australian Catholic University
}

\begin{abstract}
Pre-service education students entering university can be categorised broadly into two distinct groups, those who are coming directly from secondary school and those who are not. The second group can be quite diverse, ranging in age, academic and/or work experience. However, what both of these groups share is a digital expectation and they expect upon completion of their studies to be more digitally fluent than when they entered university, they expect to be taught via a range of digital technologies and they expect to use their digital skills throughout their personal and professional lives. These expectations have been either largely ignored or have failed to be understood by universities, resulting in a mismatch between student expectations and their experiences. However, the teaching staff within universities may be ill-prepared to meet these demands, either due to being non-users or exhibiting the same or lower levels of digital fluency as their students. The mismatch between student expectations and the reality is highlighted by an empirical case study involving undergraduate students enrolled in pre-service education degrees at an Australian university. The study will present clear evidence that students' digital expectancy should be considered when planning and improving learning environments.
\end{abstract}

\section{Introduction}

Today's students use technology (IM, Facebook, Flickr, Skype) to be constantly connected - to friends family, information and entertainment. Technology allows them to connect with more people, in more ways, more often.... The current generation seamlessly transition between their 'real' and digital lives (BECTA, 2008a, p.12).

The quote above would describe the majority of students who enter higher education immediately after completing their secondary schooling. They have been born into a digital world, however those students who have not recently completed secondary schooling, would be best described as having varying levels of digital experience. Educators face the constant challenge of refining teaching and learning techniques to keep up with the increasing demands and expectations of all students engaged in higher education, regardless of pathway (i.e. immediately from school or not) whom in this paper have been described as digitally expectant. However, it is not only the expectations of students that need to be considered; increasingly other stakeholders are becoming involved. There is an expectation expressed by parents, employers, and the wider community that the education system needs to produce technologically fluent students, who can use a wide variety of digital technologies across disciplines and professions, and who have the behaviours and knowledge that will enable them to use emerging technologies. 
How are stakeholder expectations being expressed? In a variety of ways but primarily in the form of calls for education reform; education policy documents; consultation papers; professional associations; and in the media. Tied up with the issue of digital expectations are other concerns such as equipping students to be lifelong learners and participants in the global information society. It is within this context that this paper is situated.

It is clear there is a growing demand to produce digitally fluent graduates in each phase of schooling. However, there exists a mismatch between what students, parents, employers and the wider community expect our education systems to produce and what it is actually resulting in across all phases of schooling. Sitting between these two issues are teachers, who have the role of negotiating between curricular demands and stakeholder expectations. Calling for a re-working of curriculum and syllabus documents is all well and good, but there is a sense of immediacy with this problem, and reform takes time. Education documents explicitly state that technological skills and preparing students to be 'global citizens' and 'lifelong learners' are aims. However, it is apparent to many that this is not being achieved. It falls upon teachers to try and address this issue. This mismatch that has been identified has received little attention in research. Whilst official education documents such as policy, syllabi and curriculum documents have stated that these are aims of the education system as a whole, few studies have examined whether the outcomes are achieving those aims. There is also a sense of not understanding the students who are entering our education system, understanding in a sense of knowing their technological behaviours, abilities and aptitudes in order to develop those skills. As Prensky (2001) has suggested, our current education system has not been designed with today's students in mind. This could be extrapolated to include our society's needs, employer's needs, parental expectations and global citizenship needs. The starting point for meeting these needs and expectations is to understand who our students are and from this point education can be mapped to include all of the stakeholders who participate in our education system.

This paper will focus on the digital expectations of students engaged in the tertiary phase of the education system. It will report on the findings of a 2009-2010 study that had been designed for pre-service education students enrolled in a Bachelor of Education program in an Australian university. The project was concerned with determining the digital experiences and behaviours of a typical undergraduate student cohort. The purpose was to develop an impression of the characteristics of the students, as an instrument to inform how these may impact on the way education is delivered in a tertiary setting. It will also provide some information on how faculty may adapt their current teaching strategies to accommodate, and more importantly extend the digital needs of such student cohorts. As teaching professionals it is crucial that we seriously consider the digital experiences and capabilities of our students within the learning context if "learning" is to remain meaningful and if we are to consider the expectations of all stakeholders in the education equation.

\section{Literature review}

Traditional notions of education are no longer sufficient to prepare a workforce for a contingent and dynamic world. Currently, we live in an era driven by information, global competition and new technologies that are changing the way we think, live and work. The Industrial Revolution was built on machinery, skills and labour; however, the information and knowledge-based revolution of the 21st Century is being built on 
investment in intellect and creativity. New jobs are emerging which require a different set of knowledge, skills and attitudes (Pillay, Boulton-Lewis \& Wilss, 2004, p.17).

As the world becomes more interconnected and global markets for skills and innovation develop even further, it will be crucial for Australia to have enough highly skilled people able to adapt to the uncertainties of a rapidly changing future. Higher education will clearly be a major contributor to the development of a skilled workforce (DEEWR, 2008, p.11).

As articulated by Pillay, Boulton-Lewis and Wilss (2004) and The Review ofAustralian Higher Education (DEEWR, 2008) above, there is a growing sense amongst educationalists that the knowledge-based society in which we are currently situated requires a rethinking of the skills and knowledge traditionally disseminated by higher education. Digital competence, the confident and critical use of information and communication technologies (ICT) for employment, learning, self-development and participation in society (Ala-Mutka, Punie \& Redecker, 2008, p.4) is an expected attribute of a skilled workforce. This movement parallels developments in teaching and learning which have seen the embedding of ICTs via online learning, and the use of digital tools and learning platforms across higher education institutions (Brooks \& Everett, 2008; Duncan-Howell, 2008; Duncan-Howell \& Lee, 2007; Lofstrom \& Nevgi, 2007).

\section{Learning in higher education}

Learning within higher education is not a secular process and increasingly stakeholders are playing a greater role in directing educational outcomes. What is common across all stakeholders is a shared digital expectation. Students, their parents, their future employers and increasingly, the government, expect upon completion of their studies that they will be more digitally fluent than when they entered university (Duncan-Howell, 2008). They expect to be taught via a range of digital technologies (Duncan-Howell, 2008; Duncan-Howell \& Lee, 2007; Dye, 2007; Reinhart, 2008) and they expect to use their digital skills throughout their personal and professional lives (Bruns, 2007; Jenkins, 2006). In this final stage of formal education there is a renewed focus on the skills and work-readiness of graduates, and digital expectations have been either largely ignored or have failed to be understood by universities (Duncan-Howell, 2008) resulting in a mismatch between stakeholder expectations and the reality of student experiences. Digital expectancy is placing new challenges on tertiary education. Teaching staff within universities may be ill-prepared to meet these demands, either due to being non-users or exhibiting either the same or lower levels of digital competency as their students. Universities may misinterpret digitalising their curriculums as implementing the use of online learning management platforms, which collectively result in low digital learning outcomes (BECTA, 2009).

\section{Current student cohorts in higher education}

The prevalence of digital technologies in our lives has meant that students have different needs, goals and skill requirements from previous generations, hence the need for new disciplinary methodologies to provide students with the skills required to contribute meaningfully to society. This implies redefining the parameters of traditional higher education (Guitert, Romeu, Guerrero \& Padros, 2008, p.480). There has been much commentary on current student cohorts, having been labelled 'digital natives' (Prensky, 2001) or the 'Net generation' (Tapscott, 1996). However, the reality is far from what has been prophesised (Bennett, Maton \& Kervin, 2008; Duncan-Howell 
\& English, 2011; English \& Duncan-Howell, 2008; Kennedy et al, 2008; Oliver \& Goerke, 2007). Whilst the use of digital technologies has been widespread, it has been most commonly a recreational, not a scholastic pursuit. Students have lower levels of skills than would have been expected (Bennett, Maton \& Kervin, 2008; English \& Duncan-Howell, 2008; Duncan-Howell \& Lee, 2007; Kennedy et al, 2008; Oliver \& Goerke, 2007). Given that the modern workplace requires ICT-literate knowledge workers, it is imperative that students attain the skills required to succeed (Stone, Hoffman, Madigan \& Vance, 2006, p.117). Hence there appears to be a need for higher education institutions to implement changes to disciplinary methodologies, to 'ramp up' the amount of digital upskilling across disciplines. It is interesting to note that whilst the vernacular of online learning, elearning and digital competency has been prevalent in higher education discourses, there has been little focus on determining levels of skills in graduate outcomes. An illustration of this lack of focus was the Australian Government's Graduate Skills Assessment Project that examined outcomes such as critical thinking, problem solving and interpersonal understandings (Hambur, Rowe \& Luc, 2002, p.10). Digital competency was overlooked.

\section{Higher education and digital competency skills}

Criticisms of graduate outcomes have been increasingly prevalent (BECTA, 2008b; BECTA, 2009; DEEWR, 2008; DEEWR, 2009) and universities have attempted to answer many of those criticisms. Within Australia, examples of these attempts have included: the Vice Chancellor of the University of Melbourne, Professor Glyn Davis, has switched the traditional program offerings to a more general skill-based undergraduate program based on the Bologna Process of higher education, in a bid to produce graduates with a broader and more general skill-base; other institutions have sought reform by the development of detailed graduate attributes, for example the Australian Catholic University (ACU, n.d.). A survey of graduate outcomes across Australia clearly shows the development of ICT skills as a key component, but it would appear that this outcome is failing to be met (Ala-Mutka, Punie \& Redecker, 2008; Koppi, Sheard, Naghdy, Chicharo, Edwards, Brookes \& Wilson, 2009; Pillay, Boulton-Lewis \& Wilss, 2004). Learning management programs, such as Blackboard, are being used as a general panacea by higher education disciplines as a means of satisfying technology outcomes. What has been overlooked is the difference between use of ICTs as teaching tools and the development of ICT skills in graduates. A recent government report, Transforming Australia's Higher Education System (DEEWR, 2009), reinforces the need for ICT skills in graduates. Hence there is a growing sense that the reality of digitality in higher education may not be what is expected by stakeholders.

\section{The call for reform in higher education in Australia: Discipline-specific digital competency}

The vision for higher education in 2020, as set out in The Review of Australian Higher Education (DEEWR, 2008) is to produce graduates with knowledge, skills and understandings for full participation in society as it anticipates and meets the needs of the Australian and international labour markets (p.36). Presently higher education institutions are not well placed to meet that vision and it has been suggested that we are in danger of falling behind the performance of other Organisation for Economic Co-operation and Development (OECD) countries (DEEWR, 2008; DEEWR, 2009; Pillay, Boulton-Lewis \& Wilss, 2004). The Council of Australian Governments (COAG) has commenced work on the Digital Education Revolution aimed at making better use of 
ICTs to improve educational outcomes, boost outcomes and energise the learning experience (COAG, 2008, p.3) within the schools sectors. Further, in May 2008, a Joint Ministerial Statement on ICT in Australian education and training: 2008-2011 stated that "Australia will have technology enriched learning environments that enable students to achieve high quality learning outcomes and productively contribute to our society and economy" (COAG, 2008, p.4). Clearly, the development of ICT skills for students is well underway. These initiatives will develop basic ICT skills in school-aged students; however, what is missing is the development of discipline-specific ICT skills for the workplace. This is an area of weakness in current higher education programs (AlaMutka, Punie \& Redecker, 2008; DEEWR, 2008; Koppi, Sheard, Naghdy, Chicharo, Edwards, Brookes \& Wilson, 2009; Pillay, Boulton-Lewis \& Wilss, 2004).

This need to develop discipline-specific ICT skills within higher education to ensure workforce-readiness has already been identified in the United Kingdom (BECTA, 2008b; BECTA, 2009). BECTA has released a framework entitled Next Generation Learning, a technology strategy for further education to make use of ICTs in teaching and learning. It identifies the importance of ICTs within the higher and vocational education sectors and states that "developing an e-confident workforce that has technology as an integral part of learning is an essential element of the workforce strategy for the further education sector in England" (BECTA, 2009, p.12). A strategy is needed in Australia that will build upon the initiatives in the school-sector and result in university graduates who will meet the national and workplace needs.

As the findings presented later in this paper pertain to pre-service education students, it is necessary to consider the types of skills beginning teachers need with regard to technology. Whilst this literature review has largely focused on the skills needed or expected to be acquired during the time spent in higher education institutions, many discipline areas such as education, have discipline-specific technologies. The extent to which these feature in undergraduate or postgraduate programs varies from demonstrated use by instructors to hands-on workshops. Education is a discipline area with many learning technologies, some specifically designed for discipline and some adapted technologies (i.e. those designed for other disciplines or more general use, but are adapted to educational settings). As Bates (2010) stated these discipline specific technologies should be modelled and included explicitly within programs.

This literature review has sought to clarify the context within which the need for the development of discipline-specific digital competency in higher education is situated. Graduates are preparing to enter the new global knowledge-based society, requiring digital competency for employment and to be fully-functioning members of a skilled workforce. Increasingly within this context, the concerns of stakeholders need to be accommodated and are evident in the articulated graduate outcomes of higher education institutions. It is becoming apparent that the digital competency of students engaged in higher education programs are not are high as anticipated. Digital fluency is largely confined to their personal lives, rather than their academic or professional lives. Finally, as the inclusion of ICTs within higher education has been largely as teaching tools, the development of ICT skills within programs has been generally overlooked. Within this context are the expected drivers of calls for reform, policy documents and commissioned reviews. What is clear, is that the development of discipline-specific digital competency in higher education is needed - in an attempt to start assembling the information needed to undertake this change in a meaningful and purposeful way, this paper will now present the findings of a small empirical case 
study that sought to establish the current level of digital competency within a cohort of pre-service education undergraduate students.

\section{The project}

The project involved 100 undergraduate pre-service teacher education students enrolled in a Bachelor of Education program in an Australian university. The guiding aims of the project were:

1. to examine the digital abilities and experiences of a cohort of tertiary students;

2. to explore the nature of the digital competency exhibited by the cohort; and,

3. to consider the impact of these findings on current and future learning within tertiary education settings.

The methodology utilised was a case study design which allowed for a closer examination of one specific culture-sharing group, in this case, two cohorts of undergraduate students enrolled in one program. The two cohorts comprised students enrolled in a nominated unit over two consecutive years (2009 and 2010). This was purposeful as it allowed a snapshot of students enrolled in the program over two years which enabled trends or comparisons to be made. Data was collected via an electronic survey which was conducted over a period of four weeks during a university semester.

The students were approached via email and during tutorials and were a mixture of first, second and fourth year students. This unit was purposefully chosen as it was representative of a range of completion points within the Bachelor of Education program and a broad range of areas of specialisation. Respondents included first, second and fourth year students, from Early Childhood, Primary and Secondary specialisations. The unit was a general educational studies unit with no explicit links to technology or ICTs. The potential participant pool was approximately 145, (i.e. the total number of students enrolled in the unit) and the total number of responses collected was $100(N=100)$, representing a response rate of $69 \%$.

The survey was hosted via an online website and had a consent mechanism built into the first page where respondents recorded their consent to participate in the research by selecting the 'Start Survey' button. All responses were anonymous and no personal details such as email or IP addresses were collected thereby ensuring anonymity. The survey comprised of a combination of 40 open and closed questions organised around five topics. These were (a) Introduction (b) Current ICT behaviour, (c) ICTs, (d) The Internet and (e) Higher-level ICTs.

\section{Findings}

For purposes of clarity and organisation, the findings will be presented through these five topics. The survey was designed so that the respondents were able to select more than one answer, as it was felt this would present a wider range of their experiences and behaviours.

\section{Profile of respondents}

This section of the survey contained five closed questions designed to collect broad demographic information and build a profile of the respondents. It included questions about where respondents used their ICTs and asked them to self-rate their ability. 
The majority of respondents were female (72.0\%) and aged between 17-21 years $(77.8 \%)$. The age spread was 17-36 years, with the majority being 17-21 (77.8\%), 22-26 $(14.1 \%), 32-36(4.0 \%)$ and both $27-31$ and $52+(2.0 \%)$ being outliers. They were all identified as currently enrolled in an undergraduate university degree program. The respondents were asked where they most commonly used ICTs and the results were ranked as follows: at home for personal use, at university, at home for educational or professional use, in a public place (e.g. at a library), at work and at an Internet cafe. The final question in this section asked the respondents to self-rank their abilities in ICT. The results are shown in Figure 1.

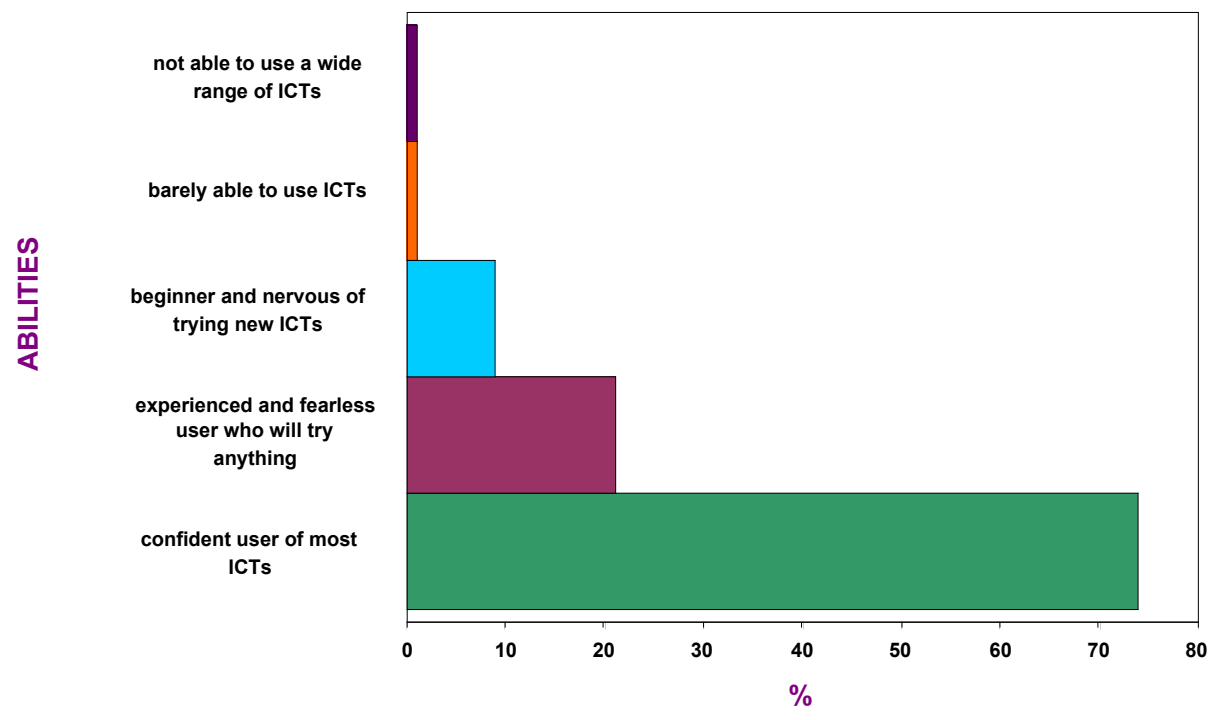

Figure 1: Self-ranked ICT abilities of respondents to the electronic survey $(\mathrm{N}=100)$

Thus this section found that in general the respondents were females aged between 17 and 21, who mostly used ICTs at home and self-rated themselves to be confident users of most ICTs. The female predominance was expected due to the program in which they were enrolled.

\section{Current ICT behaviour}

This section of the survey contained 13 closed questions with some having the option to add further details or clarification. It was designed to collect information about current ICT behaviours and determine familiarity with some key social networking programs, Web 2.0 abilities and common terms/acronyms. The respondents were asked to select from a list of acronyms associated with ICT that they were most familiar with. Those that scored most highly (>30\%) were: html, pdf, jpeg, bluetooth, bmp, gif, ppt, hyperlink, wiki, skype and wifi. Those scoring $<30.0 \%$ were: css, rss, swf, tif, pps, ISP and voip.

The participants were asked about their social networking experience, and it was revealed that the majority of respondents were currently using or had used Facebook $(73.3 \%)$. Many added further clarification to their answers, explaining that initially 
they had used many of the different features associated with Facebook, such as quizzes and games, but now mainly used what they referred to as "standard features" such as photos, superwall and messages. It would appear that communication applications were the most popular and most commonly used.

In keeping with this theme of social networking, it was clear that the popularity of online chat programs was high $(97.0 \%)$. Associated with this idea, was the use of computers to make telephone calls. It appeared that this was a common behaviour, with web-based programs that offered computer-to-computer calls, such as MSN Messenger (66.7\%) used most frequently, followed by web-based programs such as Skype $(41.0 \%)$ and VOIP phones $(5.1 \%)$. The final digital communication tool examined in this section of the survey was email. The majority of respondents maintained 1-3 email accounts $(81.4 \%)$ and web-based accounts $(95.9 \%)$ were the most popular choice followed closely by educational accounts $(89.7 \%)$, though this could be explained by the fact that the respondents were all enrolled as university students.

The respondents were asked about their use of online digital content creation sites, either as a vehicle for their own digital content or as an avenue for accessing such content. They were asked if they were familiar with YouTube and it was revealed that $89.7 \%$ had visited the site to watch videos, whilst $10.3 \%$ had visited the site to upload videos. Of those who had uploaded videos, 5-6 was the average number $(71.0 \%)$, however, some outliers had reported loading 30-50 videos to the site (29.0\%). The next digital tool examined was wikis. It was found that $38.9 \%$ visited wikis for professional reasons, $29.5 \%$ for personal reasons and $2.1 \%$ had their own wiki. Interestingly, it was revealed that $21.1 \%$ have never used a wiki and $29.5 \%$ did not know what a wiki was. Perhaps these last two results may have benefited from a definition of this term or an example. When asked to select a statement that best matched their experiences with Wikipedia, 76.3\% selected "I have visited Wikipedia many times (more than 5 times)".

Other digital tools examined were blogs and MySpace. The majority of respondents $(77.1 \%)$ did not have a blog space. However, of the $22.9 \%$ who did, they had maintained one for 3-5 years and regularly contributed to it. The number of respondents who maintained a MySpace account was $42.7 \%$, with $33.3 \%$ reporting that they had used MySpace but were no longer doing so and approximately $23 \%$ had not used nor heard of it. The respondents were asked if they had heard of Google Earth and if they had, why they had used it. An overwhelming $84.5 \%$ had heard of it and the majority of responses indicated that they had used it to look up their own or friends' houses. The final digital content examined was their ability to edit digital images. It was assumed that the respondents would be familiar with taking digital images, either by a digital camera or via mobile phones, hence the focus of this question was on what they did with those images. Of the choices, basic editing $(51.5 \%)$ was the most popular followed by experimenting with editing (32\%) and sophisticated editing (10.3\%), whilst $15.5 \%$ habitually did not do any form of editing.

\section{ICTs}

This section of the survey contained 11 closed questions, with some options for further details and was designed to collect more detailed information about the types of ICTs used by the respondents. The initial question in this section was aimed at determining in a broad sense what type of ICTs were most commonly owned. The results are shown in Figure 2. 


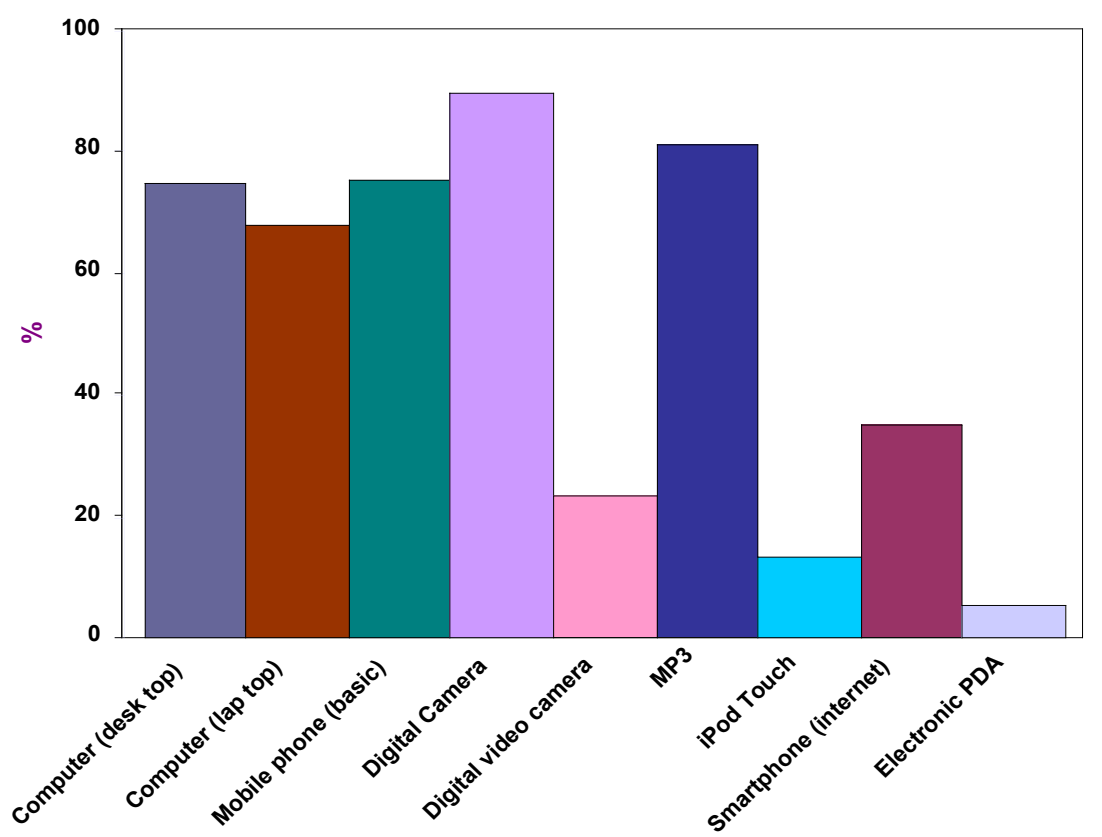

Figure 2: Commonly owned ICTs of respondents to the electronic survey

This was further examined with questions pertaining to their computer, multimedia tools, gaming and mobile phones. With regard to computers, the respondents were asked to identify the software programs they currently used or felt competent in using (they were permitted to select as many that were relevant). The most common types of programs were: MS Office suite (Word, PowerPoint, Works, Excel, Outlook), publishing programs (Adobe Reader and Publisher), web designing programs (FrontPage, Dreamweaver) and multimedia (Flash, Windows Media Player, Windows Movie Maker).

The participants were asked about their use of web-based multimedia. With regard to podcasts, respondents were either experienced in downloading podcasts $(49.5 \%)$ or were experienced in uploading podcasts for others to use (8.2\%). However, $44.3 \%$ stated that they had never downloaded one and $13.4 \%$ had never heard of a podcast. Their experiences with vodcasts were remarkably different, with $81.4 \%$ reporting that either they had not heard of vodcasts or had not downloaded one. $20.6 \%$ regularly downloaded or watched vodcasts and $5.2 \%$ had uploaded such files to the Internet. The respondents were asked if they owned an $i$ Pod, $63.2 \%$ confirmed that they did whilst the $36.8 \%$ responded negatively, this was not examined further to determine if they owned a similar type of device from a manufacturer other than Apple. The most common uses of this device were ranked as storing music loaded from their own collection, storing music downloaded from the Internet, storing digital photographs, storing podcasts and music videos, movies, TV shows and data.

Gaming proved to be a popular pastime, as all respondents stated that they had experience in playing digital games and $74.2 \%$ stated that they played them regularly. Console games were the most popular $(55.8 \%)$ followed by online games $(44.2 \%)$. Further details were asked regarding console games, they were ranked, in order of preference, as: Playstation, Nintendo, Xbox, online games and Wii. The final topic in this 
section of the survey was concerned with mobile phones and smartphones (e.g. iPhone, Blackberry). It was accepted that the majority of respondents would own a mobile phone, hence the focus of the questions was upon the features of mobiles that were most valued. As mentioned previously, more than one answer was permitted and the results are shown in Figure 3.

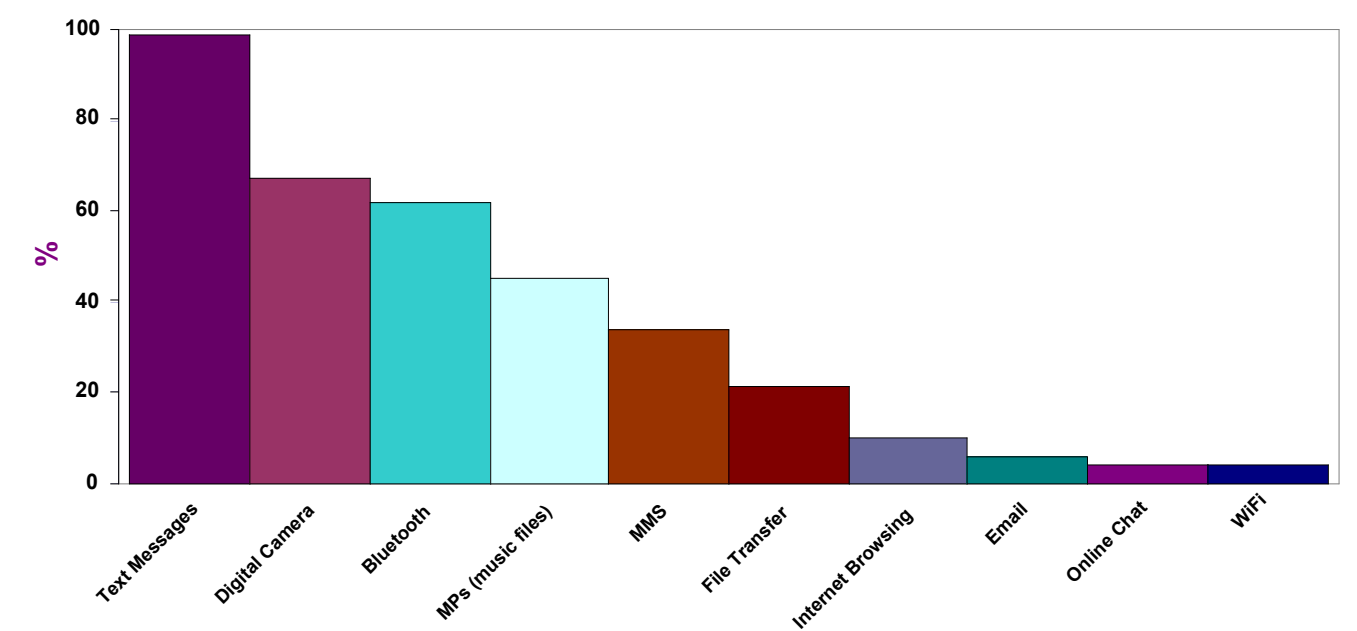

Figure 3: Most valued features of mobile phones by respondents to the survey

The final question in this section pertained to mobility. Respondents were asked to select a statement that best matched their feelings regarding this issue. The majority selected "I want to be able to move around and use my ICTs wherever I am, I do not want to be restricted" (59.8\%). Interestingly, the second ranked answer was "I generally use my ICTs at home or work, I don't need them to be mobile" $(25.8 \%)$ and finally “Mobility is important, if I can't move around I won't buy/use it" (17.5\%).

\section{The Internet}

This section of the survey contained six questions designed to collect information about the Internet behaviours of the respondents. The first question pertained to their homepage, the respondents were asked what site was their homepage and the results were ranked in order as: Google, ninemsn, their Internet provider's homepage, the university homepage, MySpace and the remaining were a mix of individually selected sites, such as news, sports, technology or other web browsers. They were asked how often they changed their homepage and $88.4 \%$ stated they did not change their homepage. Of the $11.6 \%$ who did, this ranged from once a month to once or twice a year.

The dominant Internet browser used was Internet Explorer (80.4\%), followed by Mozilla Firefox (43.3\%), whilst the choice of search engines was dominated by Google (99.0\%), Google Scholar (64.9\%) and Yahoo (17.5\%). It was interesting to note that metacrawlers, such as Dogpile, where not popular. Their stated reasons for using the Internet were ranked as follows, to find information, email, banking, shopping, paying bills, personal sites (games, dating) and for blogs. The final question in this section was about how they accessed news via the Internet, this was to determine if newer technologies, such 
as RSS feeds were being employed. It was revealed that the majority accessed news via news websites $(97.8 \%)$, followed by watching television news programs on their computer $(14.6 \%)$ and lastly via RSS feeds $(6.7 \%)$.

\section{Higher-level ICTs}

The final section of the survey contained five questions designed to explore higherlevel ICT behaviours, such as HTML coding or web page design. Initially, they were asked if they maintained their own web page, 79.4\% responded that they did not. Of the remaining $20.6 \%$ who did, most maintained this space via free webhosting $(57.0 \%)$ whilst the remainder had created their site using programs such as Dreamweaver and had then sought hosting. Regardless of whether they had a web page, $66.7 \%$ were able to use HTML codes, with levels ranging from basic to proficient. However, $73.2 \%$ were not able to use macros.

The final two questions in this section were about newsgroups and torrent drives. These were included so as to determine if the respondents were proficient in this type of technology, as it could not be defined as being a typical or widespread skill. Only $5.2 \%$ belonged to a newsgroup and $16.5 \%$ were experienced in using torrent drives. Those who did add extra information to these two questions stated that they subscribed to such sites in order to download files (multimedia) from the Internet.

\section{Discussion}

This study has revealed a series of interesting characteristics of students currently engaged in study within a higher education institution. Nearly three-quarters of the students in this cohort were identified as competent ICT users, $73.3 \%$ had used Facebook, mainly for communication purposes, and $97 \%$ used online chats and $81.4 \%$ had 1-3 email accounts. They were familiar users of iPods $(63.2 \%)$, with $49.5 \%$ downloading podcasts and $74.2 \%$ engaging in gaming. They felt that mobility was important and preferred smartphones to basic mobile telephones. These findings suggest that there is a strong presence of digital competency in the cohort of students surveyed. By definition these students have grown up in a time when use of technology and the Internet are simply a part of their lives. They did not have to learn about them at a later point in life and have used computers and mobile phones to constantly keep in contact and communicate with a wide range of people, whether known or unknown to them. It would appear that there is a constant state of 'connection', a trait that higher education pedagogies have built upon with the use of learning management systems (LMS) such as Blackboard. The digital fluency exhibited here is of a connection to a constant synchronous stream of communication with family and friends. This is something higher education institutions need to use in meaningful, learning-centred ways. For example, harnessing the use of social networking sites such as Facebook or Twitter for educational purposes, a practice that is growing in popularity amongst some practitioners within higher education (DuncanHowell \& English, 2011; English \& Duncan-Howell, 2008).

These research findings provide glimpses of how the students are constantly connected to information. However, there was no substantial evidence to indicate that besides consuming information, they were also creating content. Indications of their use of ICTs did reveal that these students were actively engaging with information resources. However, as BECTA (2008a) has cautioned, despite the fact that these students can use technology effortlessly, their level of 'digital comfort' does not 
necessarily translate it into technology proficiency - particularly with academic tools (p.9). This is a space that higher education needs to occupy, to push students beyond their digital comfort and create digital content that is discipline-specific. These types of skills and behaviours would help satisfy the expectations of future employers as the graduates will enter the professional field able to not only use, but also create digital content.

This trend has wider ramifications for higher education teaching staff. Lorenzo, Oblinger and Dziuban (2006) asserted that "faculty will need to understand new tools, databases, and searching capabilities; new bibliographic management software; new ways of assessing and teaching information literacy skills; broad and different backgrounds of students and how that influences their information literacy skills; and new pedagogies (active learning, resource-based learning, or inquiry-based learning) that engage students more directly with information resources" (p.9). They will need to reconceptualise information literacy as "a way of thinking, a dispositional habit, and a cultural practice" (Gibson, 2006). The findings so far also do not reveal if the respondents, who are most aware of the online resources available to them, are in fact any more able to use these resources in a critical and meaningful way.

\section{Conclusion}

This project sought to examine the digital technology characteristics of students enrolled in a Bachelor of Education program within an Australian university in order to inform how education is delivered and how teaching strategies could be adapted to accommodate and extend their digital competency. The findings revealed that the participants were most experienced and comfortable using social networking and Web 2.0 technologies. They clearly are proficient in their personal lives, but it would appear that it may not translate to their professional or academic lives. So what does this mean for higher education and more interestingly, graduate work readiness? The students who participated in this project clearly have some skills and an aptitude towards technology. The message higher education could possibly take from these results is that students enrolling in programs within these institutions are more digitally experienced than previous cohorts, they have strong skills in technologies used in their personal lives and possibly have more of an aptitude towards and expectation to use digital technologies in their studies and later professional lives.

Hence there is a strong need for meaningful use of digital technologies as learning tools and the development of digital professional skills within programs that is beyond the current practice of being limited to LMS use and email. Further research is needed into developing effective practices which tap the potential of the students' digital expectations. Educators need to develop strategies that more closely align with the experience, habits, and characteristics of current student cohorts. The potential is huge, and educators cannot afford to ignore it any longer.

\section{References}

Ala-Mutka, K., Punie, Y. \& Redecker, C. (2008). Digital competence for lifelong learning. European Commission Joint Research Centre Institute for Prospective Technological Studies. http: / / ftp.jrc.es / EURdoc/JRC48708.TN.pdf

Australian Catholic University (ACU) (undated). Graduate attributes. http:// students.acu.edu.au / office_of_student_success / career_development_service / for_students / graduate_attributes / 
Bate, F. (2010). A bridge too far? Explaining beginning teachers' use of ICT in Australian schools. Australasian Journal of Educational Technology, 26(7), 1042-1061.

http: / / www.ascilite.org.au/ajet/ajet26/bate.html

BECTA (2008a). Technology strategy for further education, skills and regeneration: Implementation plan for 2008-2011. London: BECTA. [verified 20 May 2012]

http:/ / archive.teachfind.com/becta/ foi.becta.org.uk/content_files/corporate/resources/foi / archived_ publications / technology_strategy_fe.pdf?resID=40511\&download_url=http: / / foi.becta.org.uk/ content files / corporate/ resources / foi / archived_publications/technology_strategy_fe.pdf

BECTA (2008b). Harnessing technology: Transforming learning and children's services. https: / / www.education.gov.uk/ publications/eOrderingDownload/1296-2005PDF-EN-01.pdf

BECTA (2009). Next generation learning: The implementation plan for 2009-2011. http: / / webarchive.nationalarchives.gov.uk/20101102103654/ http: / / publications.becta.org. uk/ download.cfm?resID $=40494$

Brooks, R. \& Everett, G. (2008). The impact of higher education on lifelong learning. International Journal of Lifelong Education, 27(3), 239-254. http: / / dx.doi.org/10.1080/02601370802047759

Bruns, A. (2007). Beyond difference: Reconfiguring education for the user-led age. Proceedings ICE3: Ideas, Cyberspace, Education. Ross Priory, Loch Lomond, Scotland, 21-23 March. http: / / eprints.qut.edu.au/6622/

COAG (2008). Success through partnership: Strategic Plan to guide the implementation of the Digital Education Revolution. Canberra: DEEWR. http: / / www.deewr.gov.au/Schooling/Digital EducationRevolution/Documents/DERStrategicPlan.pdf

DEEWR (Department of Education, Employment and Workplace Relations) (2008). The Review of Australian Higher Education. http: / / www.deewr.gov.au/HigherEducation/Review / Documents / PDF/Higher\%20Education\%20Review_one\%20document_02.pdf

DEEWR (Department of Education, Employment and Workplace Relations) (2009). Transforming Australia's Higher Education System. http: / / www.deewr.gov.au/HigherEducation/Documents/TransformingAusHigherED.pdf

Duncan-Howell, J. (2008). Digital expectancy: The impact of Generation C on tertiary education. Paper presented at The Australian Association of Research in Education (AARE) Annual Conference 27 November - 3 December, Brisbane, Queensland. [not found online 1 Jun 2012]

Duncan-Howell, J. \& English, R. (2011). Facebook goes on prac: Using social networking tools to support students undertaking teaching practicum. In T. Cox \& K. P. King (Eds.), Teaching with digital media: Best practices and innovations in higher education. Teaneck, NJ: Information Age Publishing.

Duncan-Howell, J. \& Lee, K.T. (2007). M-learning: Finding a place for mobile technologies within tertiary educational settings. In ICT: Providing choices for learners and learning. Proceedings ascilite Singapore 2007. http: / / www.ascilite.org.au/ conferences/ singapore07/ procs/duncanhowell.pdf

Dye, J. (2007). Meet generation C: Creatively connecting through content. EContent Magazine, 1 May. http: / / www.econtentmag.com/Articles/Editorial/Feature/ Meet-Generation-CCreatively-Connecting-Through-Content-35942.htm

English, R. \& Duncan-Howell, J. (2008). Facebook goes to college: Using social networking tools to support students undertaking teaching practicum. Journal of Online Learning and Teaching, 4(4), 596-601. http: / / jolt.merlot.org/vol4no4/english_1208.htm

Gibson, C. (Ed.) (2006). Student engagement and information literacy. Chicago: American Library Association. 
Hambur, S., Rowe, K. \& Luc, L. T. (2002). Graduate skills assessment. Stage one validity study. Australian Council for Educational Research and DEST Evaluations and Investigations Programme 03/02. [verified 1 Jun 2012] http:/ / www.deewr.gov.au/HigherEducation/ Publications/Documents/GradSkillsAssess.pdf

Jenkins, H. (2006). Convergence culture: Where old and new media collide. New York: New York University Press.

Kennedy, G. E., Judd, T. S., Churchward, A., Gray, K. \& Krause, K.-L. (2008). First year students' experiences with technology: Are they really digital natives? Australasian Journal of Educational Technology, 24(1), 108-122. http:/ / www.ascilite.org.au/ajet/ajet24/kennedy.html

Koppi, T., Sheard, J., Naghdy, F., Chicharo, J., Edwards, S. L., Brookes, W. \& Wilson, D. (2009). What our ICT graduates need from us: A perspective from the workplace. Proceedings Eleventh Australasian Computing in Education Conference. Wellington, New Zealand. http: / / crpit.com/abstracts/CRPITV95Koppi.html

Lee, K. T. \& Duncan-Howell, J. (2008). How do we know e-learning works? Or does it? ELearning and Digital Media, 4(4), 482-496. http:/ / dx.doi.org/10.2304/elea.2007.4.4.482

Lofstrom, E. \& Nevgi, A. (2007). From strategic planning to meaningful learning: Diverse perspectives on the development of web-based teaching and learning in higher education. British Journal of Educational Technology, 38(2), 312-324. http: / / dx.doi.org/10.1111/j.14678535.2006.00625.x

Lorenzo, G., Oblinger, D. \& Dziuban, C. (2006). How choice, co-creation, and culture are changing what it means to be net savoy. EDUCAUSE Learning Initiative. http: / / net.educause.edu/ir/library/pdf/ELI3008.pdf

Oblinger, D. G. \& Oblinger, J. L. (2005). Educating the net generation. EDUCAUSE. http: / / www.educause.edu/educatingthenetgen

OECD (2005). E-Learning in higher education: Where do we stand? http:/ / www.oecd.org/ dataoecd/54/60/34899939.pdf

Oliver, B. \& Goerke, V. (2007). Australian undergraduates' use and ownership of emerging technologies: Implications and opportunities for creating engaging learning experiences for the Net Generation. Australasian Journal of Educational Technology, 23(2), 171-186. http:/ / www.ascilite.org.au/ajet/ajet23/oliver.html

Pillay, H., Boulton-Lewis, G. \& Wilss, L. (2004). Changing workplace environments: Implications for higher education. Educational Research Journal, 19(1), 17-42. http:/ / eprints.qut.edu.au/1965/

Prensky, M. (2001). Digital natives, digital immigrants. On the Horizon, 9(5). NCB University Press. http: / / http:/ / www.marcprensky.com/writing/Prensky\%20$\%$ 20Digital\%20Natives, \%20Digital\%20Immigrants $\% 20-\%$ 20Part1.pdf

Tapscott, D. (1996). Growing up digital: The rise of the net generation. New York: McGraw-Hill.

Author: Dr Jennifer Duncan-Howell

Faculty of Education, McAuley at Banyo

Australian Catholic University

Email: Jennifer.Howell@acu.edu.au

Please cite as: Duncan-Howell, J. (2012). Digital mismatch: Expectations and realities of digital competency amongst pre-service education students. Australasian Journal of Educational Technology, 28(5), 827-840.

http: / / www.ascilite.org.au/ajet/ajet28/duncan-howell.html 